\title{
A ATUALIDADE DA MÚSICA NOS CURSOS DE PEDAGOGIA NO BRASIL
}

\section{THE CURRENT OF MUSIC IN THE COURSES OF PEDAGOGY IN BRAZIL}

DOI: http://dx.doi.org/10.5965/1984317815022019074

\author{
Anderson Carmo de Carvalho \\ Universidade Federal do Estado do Rio de Janeiro \\ anderson0carm@gmail.com
}

Celso Garcia de Araújo Ramalho Universidade Federal do Rio de Janeiro celsoramalho@musica.ufrj.br

\section{RESUMO}

O presente artigo é resultado da pesquisa realizada durante os anos de 2016 e 2017 acerca dos conhecimentos de música presentes nos currículos dos cursos de Pedagogia nas universidades públicas brasileiras. Investigamos como se apresentam as diversas denominações que ora se referem às disciplinas e ora a conteúdos, também a ausência de qualquer referência à música durante os dois últimos séculos; e como ainda hoje a música interage com os currículos de Pedagogia atuais. Parte-se da perspectiva de que o conhecimento musical é fundamental para os cursos de Pedagogia de forma não polivalente, e que há a indicação da importância do estudo do fenômeno musical na legislação que regulamenta a formação de pedagogas. Num país tão musical em que canto e dança, corpo e voz, pulsam e vibram em ações culturais e educativas, a música dimensiona o que somos e como nos tornamos humanos no Brasil. Junto ao fenômeno da música conhecemos o mundo em nosso fazer mais próprio.

Palavras-chave: Música e educação; Formação de pedagogos; Formação musical superior; Artes na pedagogia.

\section{ABSTRACT}

The present paper is the result of the research conducted during the years 2016 and 2017 concerning the knowledge of music present in the curricula of Pedagogy courses in brazilian public universities. We investigate how the different denominations that refer to the disciplines, contents or even the absence of any reference to music during the last two centuries; and how still currently music interacts with current curricula of Pedagogy. We consider the perspective that musical knowledge is fundamental to Pedagogy courses in a non-polyvalent way, and that there is the legal indication of the importance of studying the musical phenomena in the law that regulate the formation of pedagogues. In a country so musical in which singing and dancing, body and voice, pulsate and vibrate to conform cultural and educational actions, the music dimensions what we are and how we become human in Brazil. Together with the music phenomenon we know world in our most proper making.

Keywords: Music and education; Training of pedagogues; Higher education; Arts in pedagogy. 


\section{A MÚSICA NA PEDAGOGIA}

A música está presente na escola em várias faces da mesma, tanto quanto na vida humana. Intentando entender o humano, encontraremos a música na raiz da sua existência. Surpreende-nos enquanto observador que algo tão próprio do humano se torne tão distante da sua formação educacional. Não refletimos a questão da música como presença secundária, mas como sentido essencial. Música não é meio para algo, para se conhecer ou re-conhecer uma outra coisa, o fenômeno musical é ele mesmo conhecimento, é o próprio sentido de conhecer, ou seja, co-nascer, nascer junto com o gesto de saber que é o gesto de experimentar o sabor das coisas vividas, e por isso sempre presente em nossa capacidade sensível que se mobiliza para captar, estesiar, perceber e educar como ação de conduzir e provocar uma resposta que mundaniza nossa existência. Em primeira e última instância: música como ação educativa é um lançar-se para fora do humano como ato memorável.

Em nossas reflexões acerca da música na escola, pensamos o lugar da pedagoga e sua importância na história da formação humana. Para que música na formação de uma docente responsável por no mínimo dez anos iniciais de preparação escolar do humano? No que influenciaria o ensino de música para pedagogas que podem ser habilitadas para gestão escolar, orientação escolar, supervisão escolar, formação de normalistas, educação especial, pedagogia empresarial, pedagogia hospitalar e educação nos movimentos sociais e outros? E nossa pergunta de pesquisa: Como a música aparece mas grades dos cursos de pedagogia do Brasil e que resultados podemos retirar desses dados? Cabe-nos ajudar a pensar e tentar responder essa inquietação que não nos satisfaz pelas justificativas utilizadas nos tempos atuais, tais como: "música é boa para matemática", "boa para memorização de fórmulas e conteúdos demasiadamente prosaicos", "boa para leitura" ou "boa para concentração", razões funcionais e utilitaristas sempre requisitadas à música para que esteja presente na rotina escolar. Devemos caminhar com passos que, diferenciados 
dos que já foram dados, possam deslocar a música do papel secundário, servil, posto à parte e num patamar abaixo em que foi colocada pela hierarquia do saber postulado na pós-revolução científica; passos que não se apoiem somente em legislações vigentes, que não se amparem apenas nas relações estéticas recreativas, que olhem para dentro e não para fora do humano, e que trabalhem na pedagoga o reconhecimento da relação da música com sua própria existência e do outro (CARVALHO, 2017 p. 135-142).

O lugar da música está além dos números e abstrações criadas pelos homens para tentar entender o mundo e as coisas que nele habitam, a música percorre outro caminho que é diferente da epistemologia científica que atende à modernidade, as representações gráficas, numéricas e gramaticais não fazem a música ser o que ela é, e nem the fornecem o status de ciência quando busca ser controlada em tais representações. Música é concreta, pois que faz crescer, concresce como ato criativo e por isso ela é real como coisa posta numa realidade espaço-temporal inventada; a matemática, de outro modo, retira do real um dado para ser colocado no lugar da presença das coisas, isto é: uma abstração. Pode o homem examinar e conhecer toda a anatomia dos pássaros, descobrir uma técnica farmacológica, mapear suas habilidades e características sócio-comportamentais, mas não conseguirá contabilizar em dados seu canto, não poderá medir seus encantos ou desconfortos que subtraemse em sentidos. Como nos diz o poeta Manoel de Barros:

A ciência pode classificar e nomear os órgãos de um sabiá mas não pode medir seus encantos.

A ciência não pode calcular quantos cavalos de força existem nos encantos de um sabiá.

Quem acumula muita informação perde o condão de adivinhar: divinare. Os sabiás divinam. (BARROS: 2013, p.316)

Talvez as invenções encantatórias da divinação sejam insignificantes: não significáveis para essa ciência classificatória, nominativa, mensuradora, calculante e informativa? Tratar do lugar da música na formação de pedagogas é olhar além do que 
a epistemologia moderna pôde incutir na formatação de educação que hoje rege os currículos escolares.

A ciência do cálculo, a partir desse nosso olhar, somente possui hipóteses e conjecturas sobre a realidade e não certezas definitivas; as abstrações e catálogos científicos, ao nosso modo, não são capazes de conter o fluxo ininterrupto dos acontecimentos. O paradigma não para. "Perdendo o status de saber sempre certo, vem aí o lugar da filosofia e da arte, para dar à ciência a experiência da intangibilidade: talvez do sentido"' (CARVALHO, 2017, p. 120-121). A música, nas suas diversas manifestações fenomênicas, apresenta-se fora de um paradigma cientifico racional regulador, num outro sentido de ciência, saber e conhecimento: "diferentes problemas do pensamento científico deveriam, pois, receber diferentes coeficientes filosóficos" (BACHELARD, 1991, p. 14-15).

Seguimos analisando como o conhecimento de música se faz presente nas grades curriculares dos cursos de pedagogia do Brasil, observando como o conhecimento em música se apresentou na formação da professora unidocente e também da pedagoga. Através do caminho historiográfico fundamentaremos nosso recorte temporal. Objetivamos expor como hoje o estudante de pedagogia se encontra ou não com a música ao longo de sua formação, pata tanto, mapeamos durante os anos de 2016 e 2017 as grandes curriculares dos cursos de pedagogia públicos do país, coletando dados que nos encaminhassem para passos profícuos acerca do tema. A inclusão efetiva e declarada do conhecimento em música nos currículos de pedagogas de forma não polivalente possibilitará que esse conhecimento possa ser vivenciado e apreendido em sua integralidade.

Figueiredo (2003) parece ter sido o primeiro a fazer um extenso levantamento acerca da música nos cursos de pedagogia, este concentrou-se na região Sul do país. Em Dallabrida (2014) observamos que somente no período entre 2001 a 2010 foram

1 Para aprofundamento da reflexão dessa linha de pesquisa, discussão filosófica, indicamos Carvalho (2017). 
publicados na $\mathrm{ABEM}^{2}, \mathrm{ANPPOM}^{3}$, congressos, periódicos e em revistas, o número de 1.677 textos/artigos abordando os temas acerca do assunto. A autora os divide em eixos temáticos: "Musica na formação acadêmica profissional nos cursos de Pedagogia", "Música na formação continuada de professores unidocentes", "Música nas práticas educativas de professoras unidocentes" e "Temas agregados". Nestes levantamentos de textos é possível perceber o interesse que o tema fomenta no meio científico e como há um desejo em acrescentar maior conhecimento e maior acessibilidade ao tema, adicionar atitudes assertivas para inserção da música nos currículos de Pedagogia. Esse nó está presente no olhar que o professor pesquisador de música tem, sendo ele de regiões variadas desse país continental, dando-nos a perceber que nossa interrogação e inquietação não é unívoca.

A história nos será caminho para compreender os resultados encontrados, pois além de traçar um possibilidade de compreensão da trajetória da música na formação da professora primária e de pedagogas, que estão em cargos de gestão, este caminho histórico também nos permite compreender os motivos políticos e sociais do lugar que a música foi alocada formação dessa importante profissional.

\section{HISTÓRIA DO CURSO DE FORMAÇÃO DE PROFESSORES E O ENSINO DE MÚSICA}

Para início de uma pesquisa em Educação Musical no Brasil escutemos a questão que emana da própria terra aborígene; para isso nos parece necessário ressaltar que muito anterior à educação formalizada que rege nossas instituições, os índios (habitante originários), já possuíam significativa experiência com música, ou com o fenômeno que designamos de música. Por exemplo, na sociedade Tupinambá, uma sociedade rica em sonoridades, os meninos não podiam, ainda, acompanhar os pais, mas recebiam deles arcos e flechas formando grupos infantis nos quais, informalmente,

\footnotetext{
${ }^{2}$ Associação Brasileira de Educação Musical.

${ }^{3}$ Associação Nacional de Pesquisa e Pós-Graduação em Música.
} 
adentravam-se no uso desses instrumentos, além de muitos outros tipos de folguedos e jogos, entre os quais se destacava a imitação dos pássaros com maior perfeição possível (FERNANDES, 1989, p. 225). Posteriormente música também se fez presente nos primeiros passos de catequização da colônia com a atuação do Padre Manuel da Nóbrega4. "O ensino da música e do canto era, de fato, fundamental, até porque não era só um momento de introjeção de valores cristãos, mas também de transformação de costumes" (CHAMBOULERYON, 2008, p. 64). Na escola da colônia o ensino consistia em canto orfeônico e música instrumental opcional (SAVIANI, 2012, p. 43; FONTERRADA, 2008, p. 210). Se antes, na terra brasílica, o fenomeno musical brotava das ações culturais e ritualísticas no cotidiano mágico-religioso dos aborígenes, com a chegada dos "desbravadores" e "descobridores" ocorreu um embate entre "tradições musicais" a partir das imposições, colaborações e transformações que o processo de colonização engendrou. A ideia de música no Brasil passa a ser mediada pela aliança entre o poder régio e a Igreja Católica e, ainda, pelos modos e costumes dos habitantes que aqui aportaram. É essa mescla que até hoje nos instiga pensar o mistério de um Brasil que até hoje ainda não se descobriu totalmente para nós e consequentemente para a cultura escolar.

$\mathrm{Na}$ Europa, o pensamento relacionado aos espaços de formação de professores que deu início à Escola Normal nasceu na França iluminista, no século XVIII (CAMBI, 1999, p. 337). A primeira instituição com nome de Escola Normal foi proposta pela Convenção, em 1794, e instalada em Paris em 1795. Distinguia-se a escola Normal Superior para formar professores de nível secundário e a Escola, simplesmente também chamada de Escola Normal Primária, para preparar professores do ensino primário (SAVIANI, 2012, p. 16). Havia nesse momento dois modelos de formação de professores. O primeiro tornou-se referência para as universidades e o outro para as

\footnotetext{
${ }^{4}$ Manuel da Nóbrega foi um sacerdote jesuíta português, chefe da primeira missão jesuítica à América. Foi um dos responsáveis pelos primeiros passos da educação da colônia portuguesa.
} 
escolas, as artes liberais em oposição às artes manuais da práxis pedagógica (SAVIANI, 2012, p. 7)

No contexto brasileiro, foi no século XIX que o país tratou de universalizar o ensino e organizar um sistema nacional para todos. O modelo que se implantou foi o francês, resultante de nossa tradição colonial e do fato de que o projeto nacional era emprestado às elites (TANURI, 2000, p. 64). Em 1827, cria-se a Lei das Escolas de primeiras Letras. Posteriormente, criou-se a Escola Normal (SAVIANI, 2012, p. 12-14). Devemos atentar para a organização tanto do ensino regular como de um ensino de música que, paralelamente ao processo de criação das instituições escolares, erigiu o sistema dos "conservatórios", consolidado no Século XIX no Brasil, e que pode ser sintezado como modelo clássico evolucionista e ordenador para o ensino da música métrico-tonal apoiada nos meios técnico-instrumentais de representação escrita fomentando a dicotomia entre teoria e prática.

A criação do curso normal em 1835 já comportava no currículo a música e como prática o "canto coletivo". A escola contemplava o ensino musical europeu, atendendo a demanda da pequena burguesia que deseja elevar-se socialmente (FUKS, 1991, p. 98).

O conteúdo de música no ensino normal perpetua-se e se dá no Decreto 7.247, de 19/4/1879 (Reforma Leôncio de Carvalho), o qual estabelecia a primeira proposta do Poder Central relativamente às escolas de formação de professores no Brasil, servindo de modelo para algumas províncias, até para primeira escola da Corte criada em 1880. O currículo de formação de professoras deveria abranger diversas matérias, inclusive: "música vocal” (BRASIL, 1879, p. 200; SAVIANI, 2012, p. 14; TANURI, 2000, p. 67). Posteriormente, o Decreto n. 981 de 1890 a "Reforma Benjamin Constante" estabeleceu a realização de um concurso público destinado a professores especialistas em música (FONTERRADA, 2008, p. 194), sistematizando o ensino musical nos dois

5 O primeiro modelo estabeleceu-se na universidade e o segundo no ensino normal, essa característica divergente de pensamento para formação curricular perdurou por muitos anos e nos será eficaz para definir com mais clareza o porquê do ensino de música apresentar-se no formato que os dados desse trabalho resultaram. 
ciclos principais: $1^{\circ}$ grau e $2^{\circ}$ grau, bem como na instrução secundária $(2 \mathrm{~h} /$ semana somente no primeiro ano secundário) e na escola normal (BRASIL, 1890, p. 3477). No mesmo período, no curso Normal a música continua como disciplina obrigatória. As reformas de 1901 (Decreto $n^{\circ}$ 3914/01) e de 1915 (Decreto $n^{\circ}$ 11530/15) não apresentaram disciplina de música para o ensino secundário, porém esta permanece no Ensino Normal.

No início do século $X X$, movimentos educacionais da Escola Nova tomaram importância, a reforma empreendida por Anísio Teixeira perpetuou o papel da música e das artes na formação geral e na formação de música no Curso Normal (TANURI, 2000 , p. $72-73$ ). Foi por esses caminhos que se possibilitou a reformulação da instrução pública paulista, autorizando as Escolas Normais a fazerem ensaios de orfeão (FUKS, 1991, p. 100-102). O Decreto n²4.794, de 1934 criou o Curso Normal do Canto Orfeônico. m 1942, o Decreto $n^{\circ} 4.993$, de 1942, deu ênfase à formação em música para "formar candidatos ao magistério do canto orfeônico nos estabelecimentos de ensino primário e de grau secundário" (BRASIL, 1942, p. 186). Na mesma década, o ensino de música fez parte do então chamado curso ginasial, para todos os cursos técnicos, foi mantido na formação de professores normalistas. Criou-se também a Lei Orgânica do Ensino Normal (Decreto -Lei n. 8.530, de 2/1/1946), que adicionou a disciplina: Música e canto orfeônico.

Fuks nos aponta que, na primeira metade do Século XX, o método denominado "criatividade" encontrou espaço nas discussões educacionais acerca do ensino de arte, a música agora faria parte de um todo que poderia ser realizada de forma livre (FUKS, 1991, p. 139). Em seu livro, Fuks descreve o depoimento de um professor de música acerca do pensamento do método da "criatividade" na década de 60 , que diz: "não é mais preciso o conhecimento das notas musicais, agora é a época da criatividade e não é necessário saber mais nada" (FUKS, 1991, p. 126). Uma visão diametralmente oposta à rigidez dos conservatórios de música. Tanto o método da "criatividade" quanto do "conservatório" devem ser pensados de forma crítica e não como propostas inconciliáveis ou excludentes. 
Tanuri (2000) afirma que a LDB de 1961 não trouxe significativas modificações para o curso Normal. Com relação ao estudo da música, o Decreto n 51.215 , de 1961 estabeleceu normas para a educação musical nos Jardins de Infância, nas Escolas Pré-Primárias, Primárias, Secundárias e Normais em todo o país, dando para música sua última presença unívoca no ensino básico, quando, então, a LDB de 1971 definirá o conceito de educação artística pela Lei 5.692 de 1971 (BRASIL, 1971), fazendo da música uma das linguagens artísticas, sendo as outras as artes plásticas e o teatro. "O que se buscava era possibilidade de desenvolver a sensibilidade pelas artes e o gosto pelas manifestações artístico-estéticas" (LOUREIRO, 2008, p. 69).

O ensino de música no curso de normalistas passa a ser direcionado pelos elementos da pró-criatividade (FUKS, 1991, p. 146). O decreto n 51.125 no Art. $5^{\circ}$ sinaliza que a educação em música nas escolas secundárias e Normais terá finalidades polivalentes e não específicas ampliando os conhecimentos da História da Música, geral, e nacional relacionando-a intensamente à História Universal e, sempre que possivel, às outras artes, através ilustrações, projeções comparativas especialmente elaboradas para tal finalidade, entre outras finalidades (BRASIL, 1961). A LDB não faz menção ao termo "Educação Musical", sequer ao termo "música", mas sim ao termo "atividades complementares de iniciação artística".

O ensino de música sempre esteve presente na Escola Normal, seja o método utilizado mais teórico, orfeônico, mais livre ou tendo a interdisciplinaridade com outras artes, foi sempre impulsionado pelos valores pedagógicos de seu tempo. Acreditamos que o ensino da música esteve presente na formação de normalistas por ser vista como objeto prático na atividade docente, algo lúdico que auxiliava nas interações da rotina escolar e das festas comemorativas de datas especiais ${ }^{6}$. Música, nesse contexto, ao nosso olhar, torna-se material para algo, não se volve eixo principal de

6 Cabe ressalvar que nosso intuito nesse trabalho não é desmerecer esse espaço da música que também é importante na configuração do fazer-se humano. As festas, comemorações, louvores e etc, também são importantes marcos, nossa análise se apropria dessa narrativa como limitada quando a mesma se torna única e primeira perspectiva de relacionar educação e música num lugar restrito desconsiderando a perspectivação originária da música como base de todo saber, ou seja, proporcionar nos sabores da música os saberes e modos de conhecer mundo como educar-se mutuamente. 
conhecimento para o aluno, diferenciando atividade musical e educação musical. Podese observar esse aspecto no relato dessas normalistas: "É só pegar a melodia do "Ciranda cirandinha" e colocar "a nossa sacolinha vamos agora pendurar" (FUKS, 1991, p. 77).

Nas décadas de 1980 e 1990, há um silêncio que Fuks (2005) denominou de "anticanto", ou falta de canto na escola. Nos anos 2000, Fuks debruçou-se pela mesma temática e constatou uma perpetuação desse silêncio. $O$ que concluímos com esse levantamento é que seja como um conhecimento técnico, ou uma experiência interdisciplinar ou um elemento de lazer na festa escolar, o fenômeno musical sempre esteve na formação do professor do ensino de base no Brasil.

\section{O CURSO DE PEDAGOGIA E O ENSINO DE MÚSICA}

Os cursos em nível de graduação para formação de professores que lecionariam para as escolas normais têm sua origem na concepção da Faculdade de Educação, Ciências e Letras com a criação do Decreto n.19.851 de 1931. Essa baixou o estatuto das Universidades Brasileiras e formou professores para o exercício do magistério no ensino secundário normal. Foi então que, com o advento da lei 1.190 de 4 de abril de 1939, criou-se a Faculdade Nacional de Filosofia. Esta separava a atividade profissional docente da atividade cientista. Tinha, então, entre seus objetivos iniciais a formação de professores para a Escola Normal e para os Institutos de Educação.

O decreto de 1.190/39 estruturou quatro seções principais e uma especial (didática) para o modelo de formação superior. A seção de pedagogia era constituída somente de um curso: Pedagogia. O curso funcionava pelo modelo 3+1 (três anos de bacharelado e um ano de licenciatura). Os bacharéis atuariam em cargos técnicos e os licenciados, ao concluírem o curso de didática, lecionariam nas escolas secundárias que formariam as professoras primárias. Nossa pesquisa não encontrou ensino de artes ou de música para formação curricular de pedagogas nessa fase (CARVALHO, 2017 p. $61-62)$. 
A história da formação do pedagogo comportava dimensão diferente a do curso para lecionar no ensino de base: o bacharelado em Pedagogia encerrava como concepção o atendimento aos cargos técnicos da educação, como o Ministério da Educação e as gestões escolares e políticas de âmbito educacional, enquanto o licenciado era destinado à docência de ensino normal secundário, não apresentando nenhum vínculo direto com o ensino de crianças, alfabetização, primeiros cálculos ou práticas docentes para a infância. Esse fazer cabia às normalistas. A formação em Pedagogia carecia de qualquer prática musical, apesar do Ensino Normal possuir prática em música.

O primeiro passo para introdução de ensino de artes no currículo da pedagogia se dá na sua aproximação com a educação básica. Em 19627 , o Parecer CFE de n. 251/1962 indica a necessidade de o professor primário ser formado no ensino superior, desaparecendo progressivamente o curso Normal. O grupo de matérias pedagógicas para lecionar ofertava uma disciplina optativa denominada: "cultura brasileira" 8 .

A partir da Lei 5.692/71 em seu Art. 70: (BRASIL, 1971) a educação artística na Educação Básica passa a ter característica polivalente. Observar-se-á: preceitos de expressão e comunicação, aguçamento da sensibilidade, desenvolvimento da imaginação, como também no ensinar a sentir e mesmo ensinar a ler. Ou seja, havia um âmbito geral na formação em artes que não identificava qual arte era responsável por tal intento9, resultando num enfraquecimento do conhecimento de música como componente curricular escolar.

Com relação às disciplinas ligadas à área de artes na formação do pedagogo na década de 70 , pela primeira vez observamos haver nesse período, na grade do currículo comum, uma disciplina obrigatória chamada "Educação Artística" que deveria abranger a música. Ela consta do livro "Formação do Magistério: novo sistema",

\footnotetext{
7 Observar no Anexo 2 o quadro do Segundo Marco do curso de pedagogia organizado por Cruz (2008).

8 Não foi possível averiguar se essa disciplina comportava o conhecimento de música.

${ }^{9}$ Ver Parecer n 540 de 1982.
} 
publicado em 1976 (SAVIANI, 2012, p. 48). Na década de 80 nascem discussões acerca da criação da disciplina "Fundamentos da Arte Educação" para os cursos de Pedagogia no Brasil. $\mathrm{O}$ foco dessas disciplinas era a atividade lúdica da rotina escolar.

Em 1996, é aprovada a nova Lei de Diretrizes e Bases da Educação (BRASIL, 1996). O curso de pedagogia a partir do Art. 62 , de forma indireta, passa a ter vínculo com a educação primária. Uma década depois se homologou as Diretrizes Curriculares Nacionais para o Curso de Pedagogia (BRASIL, 2006), no seu Artigo $14^{\circ}$, deu conformidade às habilitações para formação de profissionais da educação na graduação, como era já previsto no ano de 1996, na Lei n 9.394/96, e adicionou-se a diretriz de que o exercício da educação em artes deveria fazer parte da formação de pedagogas na Educação Infantil e Ensino Fundamental. A Resolução, no artigo 6, apresenta 3 núcleos básicos. Faz-se menção à didática, às teorias e metodologias pedagógicas, ao trabalho docente e à codificação das diferentes linguagens na infância e adolescência, incluindo as Artes (SAVIANI, 2012, p. 57-59). Perpetua-se o formato polivalente para as artes.

No ano de 2008, é homologada a Lei $n^{\circ} 11.769$, que retificou a LDB. Ela tinha por fim definir com maior precisão a presença da música nas escolas e, quiçá, a da formação do professor que deveria atuar nelas. Dela constou a obrigatoriedade do ensino de música, mas não a exclusividade. Queiroz (2012) aponta que a Lei 11.769/08 não pode ser observada de forma isolada ao licenciado em música, pois que seria um olhar reducionista das leis. É preciso ter a LDB de 1996 como base (QUEIROZ, 2012, p. 31). $O$ autor conclui que o artigo $n^{\circ} 62$ da LDB não aponta habilitações para atuar em áreas específicas.

A formação de docentes para atuar na Educação Básica far-se-á em nível superior, em curso de licenciatura, de graduação plena, em universidades e institutos superiores de educação, admitida, como formação mínima para o exercício do magistério na educação infantil e 
nas quatro 10 primeiras séries do ensino fundamental, a oferecida em nível médio na modalidade Normal (Brasil, 1996).

Observa-se aí que não há na lei principal (LDB de 1996), nem na Lei 11.769/08 referências claras acerca de quem pode lecionar no âmbito de habilitações. Há de ser ter nível superior e uma licenciatura. O autor ainda elabora um passo à frente que aqui nos é pertinente: Quem pode, então, lecionar música?

(...) são profissionais formados em cursos reconhecidos, especificamente em cursos de licenciatura em música. Certamente, como prevê a lei, poderão ser abertas exceções para a educação infantil, o ensino fundamental I e a educação de jovens e adultos, modalidades da Educação Básica em que atua o professor "generalista", profissional que pode ser formado em licenciatura, em pedagogia ou ter a formação mínima oferecida em nível médio, na modalidade Normal (QUEIROZ, 2012, p. 34 grifo nosso).

Ademais, as DCN de pedagogia, no artigo de $n^{\circ} 4$, atribui ao licenciado em pedagogia: VI - ensinar Língua Portuguesa, Matemática, Ciências, História, Geografia, Artes, Educação Física, de forma interdisciplinar e adequada às diferentes fases do desenvolvimento humano (BRASIL, 2006).

O pedagogo, a partir da LDB vigente (1996), pode ministrar aulas de música? Pode ele ser o responsável por esse saber? Sim. Na educação infantil, no $1^{\circ}$ Segmento do Ensino Fundamental e na modalidade da educação de jovens e adultos. $O$ pedagogo, legalmente apto a exercer aulas de música, possui formação acadêmica necessária para tal fim a partir dos dados coletados nesse trabalho? Provavelmente não. Possui experiência acadêmica significativa para valorar as possibilidades dos conhecimentos em música em instituições e movimentos sociais? Crível que não se considerarmos apenas a formação dada pelos cursos de pedagogia em nível superior. O fato de uma pedagoga, atuante, ter obtido aulas de música em algum momento da sua vida acadêmica dependerá de um jogo de sorte, pois pode ela ter passado toda

\footnotetext{
${ }^{10}$ A partir da Lei $n^{0} 11.274$ de 2006 passou a ser de 5 anos o $1^{\circ}$ Segmento do Fundamental.
} 
sua formação educacional tendo visto somente uma linguagem de artes. Como um conhecimento tão vivo na escola pode não fazer parte da formação do pedagogo que hoje protagoniza a formação básica?

Outro significativo passo realizado foi o Parecer CNE/CEB No: 12/201311 que teve por fim definir as "Diretrizes Nacionais para a operacionalização do ensino de Música na Educação Básica". Esse define que os cursos de Pedagogia devem incluir em seus desenhos curriculares conteúdos relacionados ao ensino de Música para a docência na Educação Infantil e nos anos iniciais do Ensino Fundamental. No artigo § $3^{\circ}$ diz:

Compete às instituições formadoras de Educação Superior e de Educação Profissional: III - incluir nos currículos dos cursos de Pedagogia o ensino de Música, visando o atendimento aos estudantes da Educação Infantil e dos anos iniciais do Ensino Fundamental (BRASIL, 2013).

Entretanto, no ano de 2016, a Lei n 13.278/2016 recua os avanços relacionados ao ensino de música, retirando a obrigatoriedade da música no ensino básico. $A$ lei mencionada recoloca o ensino de música na mesma paragem que esteve em 1971, quando, então, o ensino de artes torna-se polivalente.

Nossa pesquisa historiográfica nos possibilita observar que a história do curso de pedagogia do Brasil inicialmente não tem por finalidade a educação primária e a práxis da rotina escolar, mas sim a reflexão acadêmica. Porém, a atividade e o conhecimento de música sempre estiveram presentes na formação do curso Normal, que era o responsável pelo ensino de base, assim sendo acreditamos ser possível concluir o porquê do conhecimento de música estar ausente da grade dos cursos de pedagogia. Aliado a isso, as leis relacionadas à educação e arte no país perpetuam a equivocada convicção na qual se pensa que arte é um só conhecimento, possível de ser ensinado numa formação polivalente. Formato que pretende que um profissional lecione várias disciplinas de arte ao mesmo tempo. Adiciona-se a essa visão turva que

11 O Parecer CNE/CEB No: 12/2013 até o presente momento não foi homologado. 
perpetua uma educação artística polivalente sob a alcunha de "artes", a ideia de que o ensino de Artes Plásticas/Visuais resolve a questão da presença das "artes" no currículo escolar, fato confirmado pelos livros de "Historia das Artes" que são verdadeiramente livros de história das artes plásticas, visuais e arquitetura, como se o teatro, literatura, música e dança não fizessem parte da "História das Artes". Fatores políticos, econômicos e sociológicos ainda necessitam ser pensados para compreendermos os desvios que retiraram a presença da música no currículo das pedagogas ao longo do Século XX, principalmente.

\section{METODOLOGIA PROPOSTA PARA PESQUISA}

Entre os anos de 2016 e 201712, fizemos um levantamento de diversas matrizes curriculares de cursos presenciais de todo o Brasil por região na seguinte sequência: sul, sudeste, centro oeste, nordeste e norte. Para esse fim, nos debruçamos sob o site do Ministério da Educação do Brasil em que se encontra a página do e-MEC. Nessa página da internet foi possível fazer uma busca regional através de um mapa do Brasil que é apresentado. Posteriormente visitamos os sites das instituições públicas, tanto municipais, estaduais e federais de cursos presenciais e que também não fossem PARFOR para coletar matrizes curriculares, projetos políticos pedagógicos ou ementas quando nos surgia dúvida sobre a disciplina. Acrescentamos que não poucas vezes, os sítios informativos das universidades apresentam links quebrados ou até mesmo documentos que já não estavam em vigor, documentos sem títulos ou datas e grades curriculares incompletas. Para tanto, também utilizamos o contato telefônico e por esse meio solicitávamos o PPP ou a matriz curricular do curso de pedagogia da instituição por email para que tivéssemos melhor acesso aos conteúdos com relação à presença da música nesses cursos. Com os documentos em mãos utilizávamos a ferramenta de busca do programa com as palavras: "arte", "artística (o)", música, musicalização, posteriormente fazíamos uma busca mais detalhada das informações que gostaríamos

12 A tabela completa pode ser encontra nos anexos do trabalho de Carvalho (2017). 
de obter: encontrar disciplinas de música, se não de artes no formato polivalente ou com outros nomes não visíveis pela ferramenta de busca.

Desse material, organizamos as tabelas A, B, C, D e E, organizadas por região e com observações da pesquisa, podendo obter uma visão geral do contexto. Durante a busca nos surgiu uma outra questão: se, o fato da universidade possuir um curso de música influenciaria a presença de uma disciplina de música na grade de Pedagogia? Também, intentamos responder essa questão na pesquisa, questão que não era inicial. Outro passo foi saber se disciplinas exclusivas de música encontradas eram lecionadas por licenciados em música, porém não conseguimos uma resposta conclusiva, apenas uma hipótese.

\section{ANÁLISE DOS DADOS COLETADOS}

Em sua ampla maioria os cursos de pedagogia têm uma disciplina, de um semestre, que aborda a temática de arte, atendendo assim as DCNs do curso de Pedagogia e a LDB, a maioria de cunho polivalente. Algumas vezes apontam para duas atividades de arte, por exemplo: música e artes visuais/plásticas. Outras com tema mais específico em uma só linguagem, geralmente: visuais/plásticas. Poucas apresentavam artes cênicas/ teatro nas ementas.

Foram analisadas 95 universidades públicas e 224 cursos de pedagogia que se dividem em campus dessas universidades. A tabela final de dados coletados é a Tabela 1 abaixo. A Tabela 1 foi criada observando elemento da pesquisa que nos eram representativos observar. Para tanto, indicamos a legenda a seguir: (U.P.) Universidades públicas que oferecem o curso de Pedagogia presenciais, excluindo as formações PARFOR, (G.P) - Cursos de graduação de pedagogia por campus universitário, (G.P.D) - Graduações em Pedagogia que apresentam pelo menos uma disciplina exclusiva de música, (U.P.M) - Universidades na região que possui um curso de Pedagogia e também oferecem um curso de graduação em Música, (G.MxG.P) Universidades onde o curso de Pedagogia apresentou uma disciplina exclusiva de 


\section{EDUCACÃO, \\ ARTE'S E INCLUSÃO}

música e também possuem oferta da graduação em Música, (D.M) - Disciplinas de Música que não possuem caráter polivalente, ou seja, são exclusivas de conteúdo do conhecimento em música e são ofertadas pelas universidades. Esse quantitativo é apresentado já que algumas universidades ofertam mais de uma disciplina de música, (ND) - Não encontramos nenhuma disciplina de arte (seja polivalente ou não) no PPP, matriz curricular ou fluxograma, (N) - Não encontramos o PPP, matriz curricular ou fluxograma. Sem dados para análise.

Tabela 1 - Dados Coletados por Regiões

\begin{tabular}{|c|c|c|c|c|c|c|c|c|}
\hline Regiões & U.P & G.P & G.P.D & U.P.M & G.MxG.P & D.M & ND & N \\
\hline SUL & 20 & 33 & 5 & 8 & 4 & 5 & 1 & 3 \\
\hline SUDESTE & 27 & 60 & 10 & 14 & 6 & 18 & 3 & 2 \\
\hline CT. OESTE & 9 & 20 & 2 & 3 & 1 & 5 & 0 & 0 \\
\hline NORDESTE & 28 & 86 & 5 & 10 & 1 & 9 & 1 & 0 \\
\hline NORTE & 14 & 32 & 3 & 9 & 4 & 8 & 2 & 6 \\
\hline Total & 95 & 231 & 25 & 44 & 16 & 35 & 7 & 11 \\
\hline
\end{tabular}

Isso nos deu um quadro de como o Brasil vêm atribuindo espaço para música na formação de pedagogas. Os dados gerais ressaltam que passos longos ainda precisam ser realizados para inserção da música nessas formações. Apenas $11 \%$ das universidades públicas do país apresentam pelo menos uma disciplina de música, não polivalente, em suas grades curriculares (Figura 1). 


\section{EDUCACÃO, ARTES E INCLUSÃO}

\section{Relaçăo entre cursos com ou} sem disciplina de Música

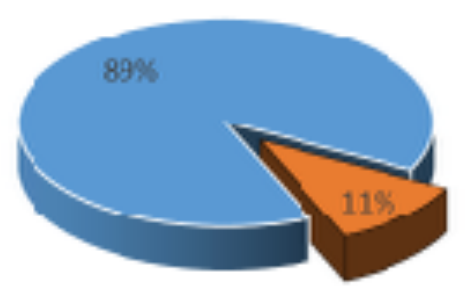

= U3̈ posvem $\square G . P D$

Figura 1 - Relação entre cursos com e sem disciplina de Música. FONTE: Gráfico elaborado pelo autor.

Quando observamos a relação de oferta de graduações de pedagogia e as graduações que ofertam pelo menos uma disciplina de música em um de seus campi, notamos percentagens baixas até mesmo entre as regiões. O gráfico abaixo (Figura 2) apresenta essa análise e também, na barra em cinza, cursos em que não encontramos nenhuma disciplina de artes. 


\section{Relação de G.P e G.P.D}

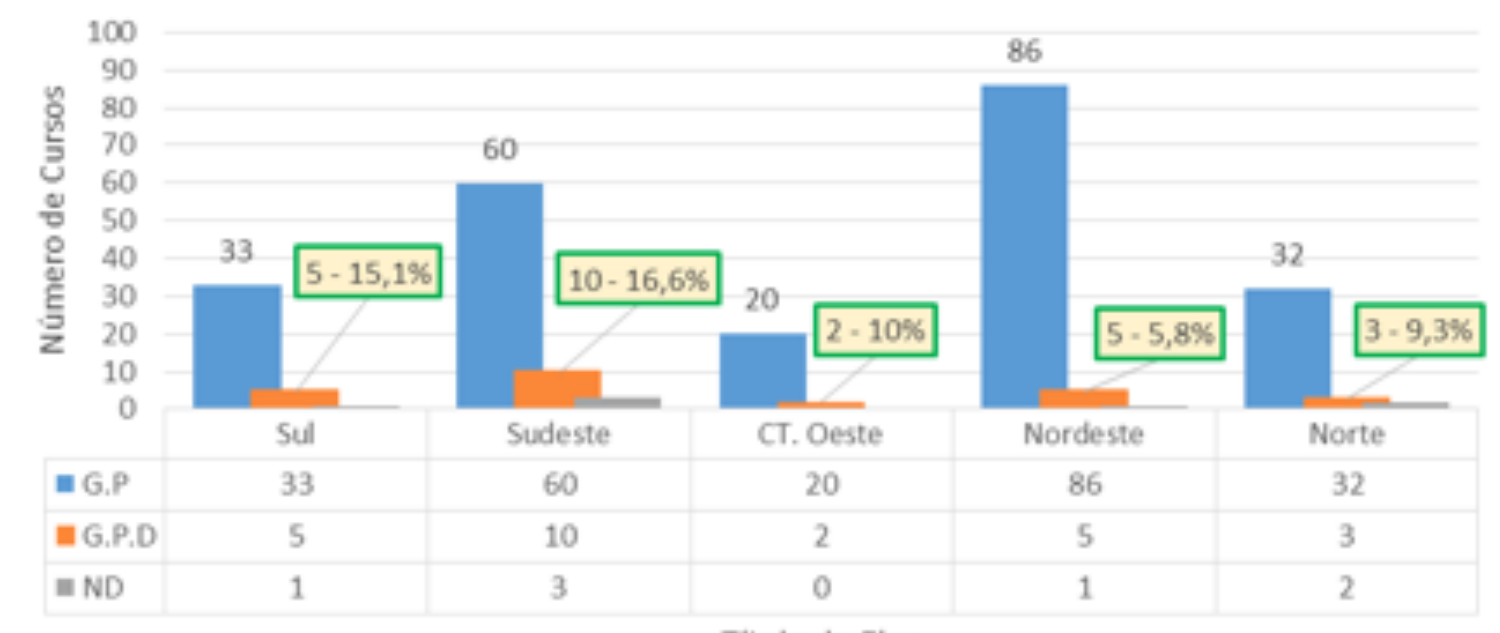

Titulo do Eixo

$=G . P=G . P . D=N D$

Figura 2 - Relação de cursos de graduação de Pedagogia por campus universitário com graduações em Pedagogia que apresentam pelo menos uma disciplina exclusiva de música

FONTE: Gráfico elaborado pelo autor.

A região Sul do Brasil parece-nos apresentar maior presença dessas disciplinas, provavelmente por possuírem universidades mais antigas e por terem maior atividade acerca do tema nas extensões e pesquisas. Com relação aos cursos de pedagogia que não oferecem nenhuma disciplina de artes, como se pode observar na barra de cor cinza, esses são minorias.

Ao nos depararmos com esses conteúdos, nos perguntamos se o fato da universidade ter um curso de música, ou departamento de ensino de música, influenciaria na criação de disciplinas de música para o curso de pedagogia. Concluímos que nem todas as universidades que possuem curso de música possuem nas grades de pedagogia algum tipo de disciplina em música, mas não conseguimos identificar essa causalidade pelos números (colunas "U.P.M" e "G.MxG.P"). Ao que podemos observar por números é que não há uma influência ou diálogo dos cursos de música sobre as graduações de pedagogia para inserção de uma disciplina de música. 
Como pode se observar, apenas algumas "U.P.M" apresentam a relação "G.M x G.P”. A Figura 3 apresenta esse entrecruzamento de dados.

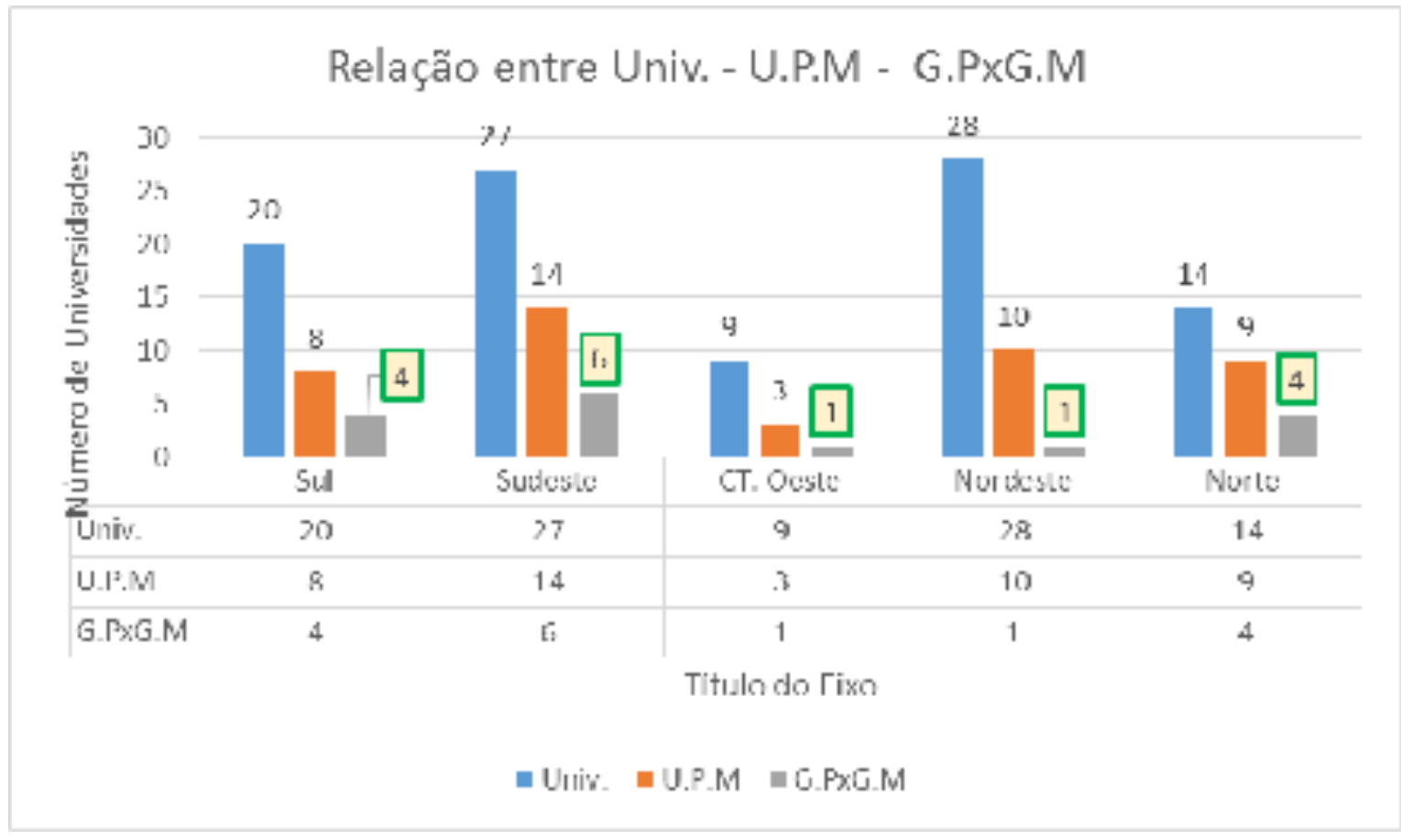

Figura 3 - Relação entre Universidades na região que possui um curso de Pedagogia e também oferecem um curso de graduação em Música e Universidades onde o curso de Pedagogia apresentou uma disciplina exclusiva de música e também possuem oferta da graduação em Música.

FONTE: Gráfico elaborado pelo autor.

Outros apontamentos nos são pertinentes sobre esse levantamento de dados, que podemos denominar como um voo panorâmico. Ciente de que não obtivemos cem por cento dos dados e que há uma imensidão de documentos que estão em constante transformação, esse trabalho é um recorte temporal. Não há presunção de nossa parte de que nossa perspectiva seja definitiva, mas acreditamos que essa divulgação de dados recolhidos num limite espaço-temporal possa ajudar outros pesquisadores dessa e de outras áreas, para tanto, apontamos para as seguintes atividades e conclusões acerca desse levantamento:

- O levantamento historiográfico responde o reflexo dos dados coletados nesse trabalho. A música sempre esteve presente, porém subutilizada devido às 
questões levantadas. A música, por sua essência não representacional, não estabeleceu lugar como ciência exata e os dados demonstram uma atualidade que reflete a história.

- Não era nossa intenção observar o estado da arte nos currículos de Pedagogia, a característica da polivalência de artes no país, relatado na história do curso, nos fez recolher dados dessa forma. Temos um estado da arte que nos possibilitou observar a música dentro da visão hegemônica da polivalência das artes.

- Apesar de termos incluído nos dados disciplinas de teatro esse não foi nosso aspecto principal de busca. Uma pesquisa focada para teatro pode apresentar uma realidade mais acertiva.

- Em uma mesma universidade há campus que possuem disciplina de música e outros não. Há outras universidades que apesar de possuírem muitos campus, apresentam somente uma grade curricular, ou somente um PPP para todos eles, sendo assim, não é fácil encontrar as eletivas do curso, disciplinas eletivas que podem aparecer temporalmente podem ter passado despercebidas se não foram declaradas nas documentações coletadas por nós.

- Acreditamos que parte das disciplinas exclusivas de música encontradas nas grades puderam ser assim ofertadas pelo motivo do professor responsável ser formado em "Educação Artística: habilitação em música" ou "Licenciado em música". Como no caso da UFRJ, UFSM, UFF-Angra dos Reis e da UFRGS entre outros. Sendo assim, acreditamos que as áreas/setores se alinham pela formação acadêmica do professor aprovado no concurso. Porém, não registramos a formação de todos os docentes responsáveis pelas disciplinas exclusivas de música.

- Há uma significativa dificuldade em pesquisar em alguns sites de universidades brasileiras, tendo as vezes que procurar por tempo longo o site do curso de pedagogia, ou as documentações do curso. Quando então a universidade 
apresenta muitos campi, dependendo da universidade, o trabalho se torna quase impossível de ser executado.

- A classificação de disciplinas exclusivas de música foram realizadas ou por observação da ementa (quando tivemos acesso) ou pelo título da disciplina.

- Apesar de não escolhermos o termo ludicidade na busca, algumas ementas de disciplinas com título "Ludicidade" apresentavam o conteúdo de música na descrição do texto. O mesmo acontece em ementas voltadas para educação infantil. Isso nos aponta o olhar apenas lúdico no qual a música é visada. O tema música aparece também em disciplinas de educação física ou psicomotricidade.

- Há disciplinas que não possuem no seu título música, mas quando observamos as ementas, concluímos que são exclusivas do conteúdo de música. Essas, quando encontradas, nós adicionamos como disciplina de conteúdo exclusivo de música. Por exemplo, uma disciplina chamada: Arte Educação II.

- Há uma predominância da presença das artes visuais/plásticas nas leituras das ementas coletadas, quando polivalente ou mesmo como única linguagem na disciplina. Parte significativa das bibliografias das ementas possuem poucos livros acerca da Educação Musical.

- Dos PPP que conseguimos adquirir, na maioria, a palavra música sequer aparece em seus textos.

- Na definição de dados da tabela 1 não fizemos distinção entre disciplinas eletivas e disciplinas obrigatórias. As tabelas A, B, C ,D e E apresentam em negrito essas diferenças que entendemos também ter relevância.

- Em geral não contemplamos nesse trabalho as disciplinas denominadas "disciplinas universais" ou disciplinas de "livre escolha" oferecidas por outros cursos que não sejam a pedagogia. Por serem ofertas de outras unidades, a coleta de dados seria multiplicada de forma a causar um dificílimo alcance. Apenas adicionamos no caso da UERJ que ofertava disciplinas do curso de Artes para a Faculdade de Educação. 


\section{CONCLUSÃO}

Pensamos que a análise histórica aqui apresentada é base para esclarecer os motivos pelos quais a ausência da música nos cursos de pedagogia do Brasil não é somente uma fatalidade curricular dos nossos tempos, mas um projeto construído na gênese do curso, ademais o fato da função da pedagoga ter precisado percorrer a segunda metade do Século XX para se estabelecer enquanto função na sociedade, exerceu influência decisiva para fundamentar a carreira e sua formação curricular, ou seja, uma conquista recentíssima. Adicionado a isso, vivemos um tempo escolar que se baseia em um significativo equívoco polivalente: arte é tudo uma só coisa e pode ser lecionado por um único docente. Também refletimos acerca do pensamento póspositivista que estabeleceu uma hierarquia no conhecimento curricular, relegando a música aos degraus mais abaixo, e em primeiro, as matemáticas e as ciências exatas. Como um conhecimento tão presente na vida humana pode estar ausente da formação das professoras primeiras dos discentes da nação? Ademais, como algo tão próprio do humano pode não ser essencial na formação escolar?

Os conteúdos de música que encontramos como disciplinas exclusivas da área musical se apresentam estimulados pelo diálogo atual das políticas de Educação Musical que vem se fortalecendo durante as primeiras décadas do Século XXI, e junto a isso, a extinção da graduação polivalente com habilitações específicas possibilitou a presença de novos professores formados dentro de áreas específicas como a Licenciatura em Música (ou Educação Musical e demais denominações), além das outras artes em suas especialidades, para que assumam o setor referente ao núcleo de artes nas graduações em pedagogia.

Nossos passos percorrem a pesquisa e o desejo intermitente da inclusão do conhecimento em música de forma assertiva nas formações de pedagogas, não por ser mais um conhecimento, mas por considerar que a música é a base de todo conhecer em que se fundam nossas memórias mais primitivas para que se desdobrem 
posteriormente em formas abstratas e demonstrativas: desde a presença da vocalidade mais familiar até a construção sonoro-musical dos ritmos e timbres que compõe o ambiente cultural em que nos educamos, e ainda por ser a música o próprio do existir humano; para tanto, a unidocente, pedagoga, "pensadora da educação", não pode deixar de experienciar um conhecimento que a torna tão aquilo que ela deve reconhecer em si mesma, a sua humanidade, assim poderá atuar na formação do próprio humano. Quando então trataremos da música como conhecimento essencial para pedagogas? Quando pensaremos na pedagoga como a possibilitadora da formação de um outro humano? Aquela ou aquele que compreende música desde o silêncio, nas relações intramundanas, nas tensões econômico-políticas das épocas, nos embates e conflitos de classes e no eterno desvelar autovelador, na verdade como memória, escutará vida, mundo, pessoas, poesia, não como matérias, horas-aula, nota da prova, "grade" curricular, filas por ordem de tamanho, trabalho final, recuperação, avaliação, sombras representadas, ordem e ode de comando para a rotina escolar, abstrações de um mundo poético concreto e denso a espera de um lugar para eclodir no ambiente escolar: a aula de arte, a aula de música (?). É urgente concretizar esse espaço-tempo na escola. É preciso dar passos para frente e para trás, ou seja, diferentes daqueles que a "Epistemologia Clássica" tem proporcionado como único caminhar exato e disciplinador, escutar o humano como inteiro em passos atravessados por possiblidades de outras formas de viver a educação como música de nossas ações, diferentes, não necessariamente idênticas às nossas experiências como docentes disciplinadores, pois que uma educação sem música nunca será verdadeiramente educação.

\section{BIBLIOGRAFIA}

BACHELARD, G. A filosofia: filosofia do novo espírito científico. Lisboa: Editorial Presença, 1991.: filosofia do novo espírito científico. Lisboa: Editorial Presença, 1991.

BARROS, Manoel. Poesia completa. São Paulo: LeYa, 2013. 
BRASIL. Coleções de Leis de 1961-v. V Atos do Poder Legislativo: leis de julho á Setembro. [S.I.]: [s.n.]. 20 dez. 1961a.

. Lei de 15 de Outubro de 1827. Coleção das Leis do Império (1808-1889). Manda crear escolas de primeiras letras em todas as cidades, villas e logares mais populosos do Imperio. Disponível em: <http://www2.camara.leg.br/legin/fed/lei sn/ 1824-1899/lei-38398-15-outubro-1827-566692-publicacaooriginal-90222-pl.html> Acesso em: 04 abr. 2016.

. Lei de Diretrizes e Bases da Educação Nacional. LEI N 4.024, DE 20 DE DEZEMBRO DE 1961. [S.I.]: [s.n.]. 20 dez. 1961b.

. Lei n. 5.692, de 11 de Agosto de 1971. Fixa Diretrizes e Bases para o ensino de $1^{\circ}$ e $2^{\circ}$ graus, e dá outras providências., Brasília, 01 abr. 1971. Disponível em: <http://www2.camara.leg.br/legin/fed/lei/1970-1979/lei-5692-11agosto-1971-357752-publicacaooriginal-1-pl.html>. Acesso em: 12 mar. 2016.

. Lei de Diretrizes e Bases da Educação Nacional. Lei n 9.394, de 20 de dezembro de 1996. Senado Federal, 20 dez. 1996. Disponível em: <https:// www2.senado.leg.br/bdsf/bitstream/handle/id/70320/65.pdf>. Acesso em: 04 abr. 2016.

. MEC. Parecer CNE/CEB n 12, de 04 de dezembro de 2013. Diretrizes nacionais para a operacionalização do ensino de Música na Educação Básica. Diário Oficial da União. Brasília, DF, 2014. Disponível em: <http://portal.mec.gov.br/index.php? option=com docman\&view=download\&alias=14875pceb012-13\&category slug=dezembro-2013-pdf\&Itemid=30192>. Acesso em 30 jan. 2015.

. Decreto, o Regimento Interno para as Escolas Publicas de Instrução primária. Coleção das Leis do Império (1808-1889). Disponível em: <HYPERLINK "http:// www2.camara.leg.br/legin/fed/decret/1824-1899/decreto-1331-a-17fevereiro-1854-590146-publicacaooriginal-115292-pe.html"http://www2.camara.leg.br/ legin/fed/decret/1824-1899/decreto-1331-a-17-fevereiro-1854-590146publicacaooriginal-115292-pe.html> Acesso em: 04 abr. 2016.

Decreto. Lei orgânica do ensino normal. Coleção de Leis do Brasil - 1946, Página 646 Vol. 1. D. Disponível em: <HYPERLINK "http://www2.camara.leg.br/legin/ fed/declei/1940-1949/decreto-lei-8530-2-janeiro-1946-458443-publicacaooriginal-1pe.html"http://www2.camara.leg.br/legin/fed/declei/1940-1949/decreto-lei-8530-2janeiro-1946-458443-publicacaooriginal-1-pe.html> Acesso em: 04 abr. 2016. 
. Decreto. Reforma o ensino primario e secundario no municipio da Côrte e o superior em todo o Imperio. In: Coleção de Leis do Império do Brasil - 1879, Página 196 Vol. 1 pt. II. Disponível em: <HYPERLINK "http://www2.camara.leg.br/legin/fed/decret/ 1824-1899/decreto-7247-19-abril-1879-547933-publicacaooriginal-62862-pe.html"http:// www2.camara.leg.br/legin/fed/decret/1824-1899/decreto-7247-19-abril-1879-547933publicacaooriginal-62862-pe.html> Acesso em: 06 Setembro 2015.

. Decreto. Dispõe sobre a organização do ensino secundário. Diário Official 1/5/1931, Página 6945. Disponível em: <HYPERLINK "http://www2.camara.leg.br/legin/ fed/decret/1930-1939/decreto-19890-18-abril-1931-504631-publicacaooriginal-141245pe.html"http://www2.camara.leg.br/legin/fed/decret/1930-1939/decreto-19890-18abril-1931-504631-publicacaooriginal-141245-pe.html>. Acesso em: 06 Setembro 2015.

. Conselho nacional de educação (2006). Resolução CNE/CP n. ${ }^{\circ}$, de 15 de maio de 2006. Institui Diretrizes Curriculares Nacionais para o curso de Graduação em Pedagogia, licenciatura. Disponível em: <http://portal.mec.gov.br/cne/arquivos/pdf/ rcp01 06.pdf>. Acesso em 10 fev. 2013.

. Ministério da Educação e do Desporto. Secretaria de Educação Fundamental. Parâmetros Curriculares Nacionais. Brasília, 1997. v. 6: Arte. Disponível em: <http:// portal.mec.gov.br/seb/arquivos/pdf/livro06.pdf>. Acessado em 15/10/2015

. Parecer n. ${ }^{\circ}$ 251/62. CONSELHO FEDERAL DE EDUCAÇÃO (1962). Fixa o currículo mínimo e a duração do curso de Pedagogia. Documenta. n. ${ }^{0} 11$, p. 59-66.

. Presidência da República. Lei $n^{\circ} 11.769$, de 18 de agosto de 2008. Altera a Lei no 9.394, de 20 de dezembro de 1996, Lei de Diretrizes e Bases da Educação, para dispor sobre a obrigatoriedade do ensino da música na Educação Básica. Brasília, 2008. Disponível em: <http://www.planalto.gov.br/ccivil 03/ ato2007-2010/2008/lei/ 111769.htm>. Acesso em: 27 jun 2015

. Lei 9.394, de 20 de dezembro de 1996. Estabelece Diretrizes e Bases da Educação Nacional. Diário Oficial da União. Brasília, 2011(Atualizado). Disponível em <http://www. planalto.gov.br/ccivil 03/leis/L9394>. htm Acesso em 05 abr. 2017.

. Lei $\mathrm{n}^{\circ} \mathbf{1 3 . 2 7 8}$, de 2 de maio de 2016. Altera o $\S 6$ do art. 26 da Lei no 9.394, de 20 de dezembro de 1996, que fixa as diretrizes e bases da educação nacional, referente ao ensino da arte. <http://www.planalto.gov.br/ccivil 03/ ato2015-2018/2016/lei/l13278.htm>

CAMBI, F. História da Pedagogia. Tradução de Álvaro Lorencini. São paulo: Fundação Editora UNESP (FEU), 1999. 701 p. Títutlo Original: Storia della pedagogia. 
CARVALHO, Anderson. A música na formação em pedagogia: Uma perspectiva a partir das graduações no estado do Rio de Janeiro, 2017. Dissertação de Mestrado. Escola de Música da UFRJ, 2017. Rio de Janeiro. 206p. In:

javascript:open window("https://minerva.ufrj.br/F/ 8D7K2YK8YIPQGRV5F9LE1RRSK9A8VXXCMMB24THUPA11LP5GY8-25593? func=service\&doc library=UFR01\&doc number=000861853\&line number=0001\&func code=WEB-BRIEF\&service type=MEDIA"):

CHAMBOULERYON, R. Jesuítas e as crianças no Brasil quinhentista. In: PRIORE, M. D. História das crianças no Brasil. 6ª . ed. São Paulo: Contexto, 2008. p. 55-83.

FERNANDES, F. A organização da sociedade Tupinambá. São Paulo: Hucitec/ Brasília, UnB, 1989.

DALLABRIDA, I. C. Formação musical no curso de pedagogia: (des)afiando o professor unidocente. In: X ANPED SUL, Florianópolis, 26-29 out. 2014. Anais... Florianópolis: ANPED, 2014.

FIGUEIREDO, S. L. The music preparation of generalist teachers in Brazil. 2003. 364f. Tese (Doutorado em Filosofia) - Faculty of Education, Language and Community Services, Royal Melbourne Institute of Technology, Melbourne, Austrália, 2003.

FONTERRADA, M. T. D. O. De tramas e fios: um ensaio sobre música e educação. $2^{a}$. ed. São Paulo: UNESP, 2008. 365 p.

FUKS, R. O discurso do Silêncio. Rio de Janeiro: Enelivros, v. Série Música e Cultura: I, 1991. $182 \mathrm{p}$.

O novo sentido do silêncio. Congresso da ANPPOM, 2005, [s.I.]. Anais... [s.I.]: ANPPOM, 2005. p. 100-108., 2005. p. 100-108.

LOUREIRO, A. M. A. O ensino de música na escola fundamental. $4^{\mathrm{a}}$. ed. Campinas: Papirus, 2008. 235 p. Coleção Papirus Educação.

QUEIROZ, L. R. S. Música na escola: aspectos históricos da legislação nacional e perspectivas atuais a partir da Lei 11.769/2008. Revista da ABEM, Londrina, v. $20 \mathrm{n}$. 29, p. 23-38, jul.-dez. 2012. Disponível em: <http://www.abemeducacaomusical.com.br/ revista abem/pdfs/ed29 revistadaabem.pdf. >. Acesso em: 05 jan. 2017.

SAVIANI, D. A pedagogia no Brasil: história e teoria. 2a . ed. Campinas: Autores associados, 2012. 224 p. 


\section{EDUCACÃO, ARTES E INCLUSÃO}

TANURI, L. M. História da formação de professores. Revista Brasileira de Educação: 500 anos de Educação, v. 14, p. 61-88, mai-ago. 2000. Disponível em: <http:// www.scielo.br/pdf/rbedu/n14/n14a05>. Acesso em: 03 set. 2015.

Recebido em 05 de novembro de 2018 Aprovado em 17 de março de 2020 